\title{
Antiproliferation Assay of Essential Oil of Curcuma Rhizoma (Curcuma xanthorrhiza Roxb.) Against P388 Leukemia Cell
}

\author{
Ida Musfiroh $^{1 *}$, Angga Geganaputra ${ }^{1}$, Ajeng Diantini ${ }^{2}$, Yasmiwar Susilawati ${ }^{3}$, \\ Muchtaridi Muchtaridi ${ }^{1}$ \\ ${ }^{1}$ Departemen Analisis Farmasi dan Kimia Medisinal, Fakultas Farmasi, Universitas Padjadjaran, Bandung, Indonesia \\ ${ }^{2}$ Departemen Farmakologi dan Farmasi Klinik, Fakultas Farmasi, Universitas Padjadjaran, Bandung, Indonesia \\ ${ }^{3}$ Departemen Biologi Farmasi, Fakultas Farmasi, Universitas Padjadjaran, Bandung, Indonesia
}

Submitted 05 May 2020; Revised 02 July 2020; Accepted 03 July 2020; Published 30 October 2020

*Corresponding author:ida.musfiroh@unpad.ac.id

\begin{abstract}
Leukemia or blood cancer is a disease which marked by abnormal increasing of blood producer's cells. Chemotherapies which used as anticancer have a many adverse effect and toxicity. The volatile oil of turmeric rhizome (Curcuma xanthorriza) contains sesquiterpene which has an pharmacological activity. The aimed of this research to assay the antiproliferation activity of volatile oil from curcuma rhizome to leukemia P388 cells using MTT (3-[4,5-dimethylthiazole-2-yl]-2,5-diphenyl tetrazolium bromide) method. The methods were contain of identification of volatile oil (produced from distillation water-steam) using organoleptic test and TLC, and activity test was using seven various concentrations, which were $0.1 ; 0.3 ; 1 ; 3 ; 10 ; 30 ; 100 \mu \mathrm{g} / \mathrm{mL}$. The result showed that the sample can inhibit leukemia P388 cells with the value of $\mathrm{IC}_{50}$ was $15.5 \mu \mathrm{g} / \mathrm{mL}$. The volatile oil of Curcuma rhizome has an antiproliferative activity to leukemia $\mathrm{P} 388$ cell.
\end{abstract}

Keywords: Curcuma rhizome, MTT assay, leukemia cell P388, volatile oil

\section{Uji Antiproliferasi Minyak Atsiri Rimpang Temulawak (Curcuma xanthorrhiza Roxb.) pada Sel Leukimia P388}

\begin{abstract}
Abstrak
Leukimia atau sel kanker darah merupakan penyakit yang ditandai dengan perbanyakan sel tak normal sel-sel pembentuk darah. Kemoterapi yang digunakan sebagai antikanker memiliki efek samping dan toksisitas. Minyak atsiri dari rimpang temulawak (Curcuma xanthorrhiza Roxb.) mengandung senyawa sesquiterpen yang memiliki aktivitas farmakologi. Penelitian ini bertujuan untuk menguji aktivitas antiproliferasi minyak atsiri rimpang temulawak (Curcuma xanthorrhiza Roxb.) pada sel leukemia P388 dengan metode MTT (3-[4,5-dimethylthiazole-2-yl]-2,5-diphenyl tetrazolium bromide). Metode penelitian terdiri atas identifikasi minyak atsiri (dihasilkan dari destilasi uap-air) dengan uji organoleptis dan KLT, serta uji aktivitas menggunakan tujuh variasi konsentrasi, yaitu 0,$1 ; 0,3 ; 1$; $3 ; 10 ; 30 ; 100 \mu \mathrm{g} / \mathrm{mL}$ kemudian perhitungan nilai $\mathrm{IC}_{50}$. Hasil penelitian menunjukkan bahwa sampel mengandung senyawa terpenoid, dan dapat menghambat pertumbuhan sel leukemia P388 dengan nilai IC50 yaitu 15,5 $\mu \mathrm{g} / \mathrm{mL}$. Minyak atsiri rimpang temulawak memiliki aktivitas antiproliferasi pada sel leukimia P388.
\end{abstract}

Kata Kunci: Minyak atsiri, sel leukimia P388, temulawak, uji MTT 


\section{Pendahuluan}

Leukemia atau kanker darah adalah sekelompok penyakit keganasan pada jaringan hematopoietik yang dicirikan adanya penggantian elemen sumsum tulang normal oleh sel darah abnormal atau sel leukemik, disebabkan oleh proliferasi tidak terkontrol dari sel darah immatur yang berasal dari sel induk hematopoietik. ${ }^{1}$ Data statistik kanker USA jumlah kematian leukemia sebesar 7,5 per 100.000 populasi pada tahun 2018 . Angka kematian akibat leukimia lebih banyak dibandingkan pada kasus kanker prostat dan kanker payudara. ${ }^{2}$

Secara historis, tanaman obat berperan dalam pengobatan dan pada saat ini, diketahui banyak produk alami menjadi bagian dari produk farmasi, dan sebagian besar berperan di bidang terapi kanker. ${ }^{3}$ Pengobatan pada leukemia saat ini kurang efisien, menghasilkan efek samping yang cukup besar, dan biaya cenderung mahal. Sehingga, alternatif pengobatan yang dapat dijadikan pilihan dalam tatalaksana pengobatan leukimia dapat bersumber dari bahan alam, maupun turunan dari senyawa bahan alam. ${ }^{4}$

Temulawak (Curcuma xanthorrhiza Roxb.) merupakan salah satu tanaman asli Indonesia dan secara tradisional digunakan untuk menyembuhkan penyakit diantaranya kerusakan hati, hipertensi, diabetes, kanker. ${ }^{5,6}$ Minyak atsiri rimpang Curcuma xanthorrhiza Roxb. mengandung beberapa komponen derivat seskuiterpen yaitu, alfa dan beta turmeron. ${ }^{7}$

Kadar minyak atsiri dalam rimpang temulawak bervariasi antara 7,3-29,5\% dihitung berdasarkan bobot kering rimpang. Komponen paling dominan adalah sesquiterpen fenol xanthorrhizol (32\%). Komponen utama lainnya dalam minyak atsiri yaitu $\beta$-curcumen $(17,1 \%)$, zingiberen $(13,2 \%), \quad \beta$-bisabolol $(3,5 \%)$, dan arcurcumen (2,6\%), dan mengandung sejumlah kecil senyawa kamfor. ${ }^{8}$ Xanthorrhizol adalah golongan senyawa sesquiterpen dan secara luas digunakan untuk pengobatan-pengobatan berbagai macam keadaan patologis. Xanthorrhizol telah dianalisis pada hewan percobaan yang diinduksi metastasis paru- paru dan senyawa ini dapat menginhibisi pertumbuhan tumor dan aktivitas metastasis dari sel kanker. ${ }^{7}$ Rimpang temulawak dan Xanthorrhizol juga telah diteliti untuk penghambatan kanker hati, dan kanker payudara YBM-1, MCF dan T47D. ${ }^{9-12}$

Dalam penelitian ini dilakukan uji aktivitas antikanker minyak atsiri rimpang temulawak dalam penghambatanya terhadap sel-sel leukemia sebagai salah satu alternatif pengobatan kanker. Uji antiproliferasi secara invitro dengan metode MTT (3-[4,5-dimethylthiazole-2-yl]-2,5-diphenyl tetrazolium bromide) dan pengukuran absorbansi menggunakan ELISA Reader.

\section{Metode}

2.1. Alat

Alat-alat yang digunakan dalam penelitian ini adalah timbangan digital, ELISA plate reader, Laminar Air Flow Cabinet (Clyde Apach), Inkubator $\mathrm{CO}_{2}$, High Speed Refrigerated Centrifuge (Beckman), pendingin $-80^{\circ} \mathrm{C}$, labu kultur (Nunc), pipette aid (Gilson), Inverted Microscope (Nikon), otoklaf (KLP-KP 180), alat sentriguasi (Heralus), cawan petri dan alat gelas yang biasa digunakan di laboratorium pengujian in vitro.

\subsection{Bahan}

Bahan kimia yang digunakan dalam penelitian ini yaitu minyak atsiri temulawak yang diperoleh dengan metode destilasi uap air dari Balai Penelitian Tanaman Obat J1. Manoko Lembang Jawa Barat, Silica Gel GF 254 (Merck), pengembang toluen (Bratachem), etil asetat (Bratachem), vanillin sulfat, medium RPMI 1640 (Sigma, St. Louis, MO, USA), Fetal Bovine Serum (Sigma, St, Louis, MO, USA), dimetilsulfoksida 10\%, larutan dapar fosfat/PBS (Sigma aldrich), 3-(4,5-dimethylthiazol-yl)-2,5-diphenyl tetrazolium bromide (MTT/Sigma, St. Louis, MO, USA) dan stop solution (Natrium Dodesil Sulfat, $10 \%$ dalam 0,1 N HCl).

\subsection{Prosedur rinci}

2.3.1. Identifikasi minyak atsiri rimpang temulawak 
Minyak atsiri diperoleh rimpang temulawak yang berumur 10 bulan dengan metode destilasi uap air. Sampel dilakukan pemeriksaan secara organoleptis meliputi bentuk, warna dan bau. Selain itu juga dilakukan identifikasi menggunakan Kromatografi Lapis Tipis dengan fase diam silica gel GF 254, pengembang toluene-etil asetat (99:1) serta penampak bercak sinar UV (254 dan $366 \mathrm{~nm}$ ) dan vanillin sulfat.

\subsubsection{Uji Aktivitas}

A. Penyiapan sel dan sampel

Suspensi sel dibuat sekitar $3 \times 10^{4} \mathrm{sel} /$ $\mathrm{mL}$ diperoleh dari Laboratorium Organik Bahan Alam, Jurusan Kimia, Fakultas MIPA, ITB, kemudian diinokulasikan dalam plat mikro 96 lubang dasar rata dan kultivasi pada media RPMI 1640 dan diinkubasi pada inkubator $\mathrm{CO}_{2}$ setelah penambahan $10 \%$ Fetal Bovine Serum.

Sampel minyak atsiri dilarutkan dalam $100 \mu \mathrm{L}$ DMSO (dimethylsulfoxide) $10 \%$, dan dilakukan pengenceran sampel menggunakan PBS (phospate buffer solution, Sigma Aldrich) sehingga diperoleh konsentrasi 0,$1 ; 0,3 ; 1 ; 3 ; 10 ; 30 ; 100 \mu \mathrm{g} / \mathrm{mL}$. Masing-masing larutan sampel sebanyak 10 $\mu \mathrm{L}$ ditambahkan ke plat mikro sel. Kemudian dikocok menggunakan mixer plat mikro dan disimpan kembali dalam inkubator $\mathrm{CO}_{2}$ selama 48 jam (dua hari). ${ }^{13}$

B. Uji antiproliferasi dengan metode MTT
Pada hari ke-3 dilakukan penambahan reagen MTT (3-[4,5, dimethylthiazol-yl-]2,5-diphenyl tetrazolium bromide) ke dalam masing masing plat mikro sel yang telah diinkubasi selama dua hari sebelumnya, kemudian dikocok dengan mixer plat mikro selama \pm 2 menit, disimpan kembali dalam inkubator $\mathrm{CO}_{2}$ selama empat jam kemudian ditambahkan stop solution SDS (Sodium Dodesil Sulfat $10 \%$ dalam 0,1 N HCl ) dan dikocok dengan lembut. Kemudian disimpan kembali dalam inkubator $\mathrm{CO}_{2}$ selama 24 jam. Pengukuran optical density dilakukan dengan Reader Plate Micro pada panjang gelombang $595 \mathrm{~nm} .{ }^{13}$ Kemudian dihitung nilai $\mathrm{IC}_{50}$.

C. Analisis data

Data hasil uji aktivitas antiproliferasi minyak atsiri rimpang temulawak terhadap sel leukemia P388 dianalisis menggunakan Desain Acak Sempurna $(\alpha=0,01)$

\section{Hasil}

3.1. Hasil identifikasi minyak atsiri

Hasil pemerikasaan sampel minyak atsiri rimpang temulawak secara organoleptis menunjukkan cairan berwarna kuning kecoklatan, berbau tajam, khas aromatik. Identifikasi dengan metode KLT pengembang toluen:etil asetat (99:1) menghasilkan spot warna-warna pada penampak bercak valinin sulfat. Terdapat bercak berwarna dengan nilai Rf 0,24 berwarna abu-abu, bercak dengan warna merah-ungu ( $\operatorname{Rf} 0,9)$ dan bercak warna ungu (Rf 0,6). Hasil identifikasi ini

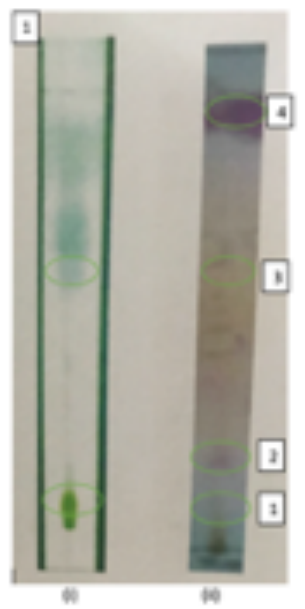

Gambar 1. Hasil Identifikasi minyak atsiri rimpang temulawak dengan KLT (fasa diam silika gel GF254, pengembang toluen-etil asetat (99:1); penampak bercak (i)UV 366 dan (ii)vanilin sulfat 
Tabel 1. Hasil identifikasi minyak atsiri rimpang temulawak (Curcuma xanthorrhiza Roxb.)

\begin{tabular}{cccc}
\hline Noda KLT & Rf & UV 366 & Vanilin sulfat \\
\hline 1 & 0,24 & Hijau & Abu-abu \\
2 & 0,38 & - & Merah muda \\
3 & 0,625 & Biru & Ungu \\
4 & 0,90 & - & Merah Ungu \\
\hline
\end{tabular}

ditunjukkan dalam Gambar 1 dan Tabel 1.

\subsection{Hasil uji aktivitas}

Hasil uji aktivitas antiproliferasi sampel minyak atsiri temulawak terhadap konsentrasi dengan nilai optical density ditunjukkan pada Tabel 2. Pada penelitian ini untuk memperoleh $\mathrm{IC}_{50}$ hasil dari pengukuran menggunakan ELISA plate reader dimasukkan ke dalam grafik semilogaritma, lalu hasil rata-rata kontrol positif (yang merupakan optical density dari medium dan sel) dibagi dua dan diplotkan ke dalam grafik. Konsentrasi yang didapatkan berdasarkan plot merupakan nilai $\mathrm{IC}_{50}$. Aktivitas sitotoksik dinyatakan sebagai $\mathrm{IC}_{50}$ yaitu konsentrasi sampel yang diperlukan untuk menginhibisi 50\% sel leukemia P388. Nilai $\mathrm{IC}_{50}$ terhadap sel leukemia P388 pada minyak atsiri temulawak dapat dilihat pada Gambar 2, dimana setengah atau 50\% nilai OD kontrol positif yaitu 0,026 diekstrapolasikan dalam grafik menggunakan kertas semilog dan diperoleh nilai $\log \mathrm{C}$ adalah 1,19. Nilai Log $\mathrm{C}$ tersebut kemudian dikonversi menjadi konsentrasi (C) dan diperoleh 15,5 $\mu \mathrm{g} / \mathrm{mL}$. Berdasarkan hal tersebut maka uji aktivitas antiproliferasi minyak atsiri rimpang temulawak menunjukkan nilai $\mathrm{IC}_{50}$ sebesar
$15,5 \mu \mathrm{g} / \mathrm{mL}$, dan menunjukkan bahwa pada konsentrasi tersebut dapat menghambat pertumbuhan sel leukemia P388 sebanyak 50 $\%$.

\subsection{Hasil analisis data dengan statistik}

Analisis data uji aktivitas antiproliferasi minyak atsiri rimpang temulawak dilakukan menggunakan perhitungan ANOVA dengan $\alpha-0,01$ ditunjukkan pada Tabel 3, diketahui $\mathrm{F}_{\text {hitung }}=3$ lebih kecil dibandingkan dengan $F_{\text {tabel }}(6,14)$. Nilai $F_{\text {hitung }}$ adalah 4,46, oleh karena itu uji aktivitas ini menunjukkan $\mathrm{H}_{0}$ diterima, artinya tidak terdapat perbedaan yang nyata terhadap pengaruh peningkatan konsentrasi yang digunakan dari minyak atsiri rimpang temulawak terjadap inhibis sel leukemia P388. ${ }^{17}$

\section{Pembahasan}

Berdasarkan pemeriksaan organoleptis sampel merupakan minyak atsiri temulawak hal ini didasarkan pada penelitian sebelumnya yang menyatakan bahwa minyak atsiri rimpang temulawak berwarna kuning kecoklatan, berbau tajam dan khas aromatik. ${ }^{10}$ Sementara itu, hasil KLT pada identifikasi sampel minyak atsiri rimpang temulawak menunjukkan

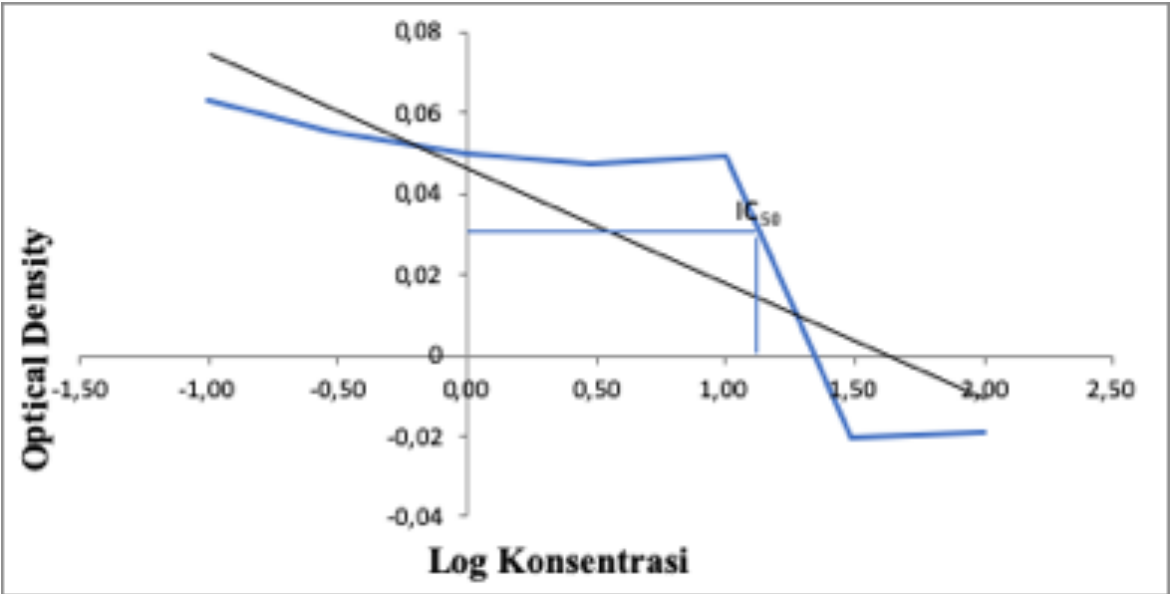

Gambar 2. Grafik $\mathrm{IC}_{50}$ minyak atsiri temulawak (Curcuma xanthorrhiza Roxb.) pada sel leukimia P388 dengan metode MTT 
Tabel 2. Hasil pengukuran optical density minyak atsiri rimpang temulawak pada sel leukimia P388

\begin{tabular}{cc}
\hline $\mathbf{C}(\boldsymbol{\mu g} \mathbf{m} \mathbf{m L})$ & Optical density (OD) $\pm \mathbf{S D}$ \\
\hline 0,1 & $0,063 \pm 0,003$ \\
0,3 & $0,055 \pm 0,002$ \\
1,0 & $0,051 \pm 0,002$ \\
3,0 & $0,046 \pm 0,003$ \\
10,0 & $0,049 \pm 0,008$ \\
30,0 & $-0,02 \pm 0,019$ \\
100,0 & $-0,019 \pm 0,002$ \\
\hline Kontrol normal & 0,052 \\
\hline
\end{tabular}

adanya beberapa senyawa, berdasarkan pada warna-warna yang dihasilkan pada sinar UV 366 dan penampak bercak valinin sulfat. Bercak berwarna diantaranya menunjukkan senyawa golongan monoterpen alkohol dan esternya yang merupakan golongan senyawa terpenoid dengan nilai Rf 0,24 berwarna abuabu, seperti salah satunya adalah borneol. Kemudian bercak dengan warna merah-ungu (Rf 0,9) menunjukkan senyawa kamfor dan bercak warna ungu $(\operatorname{Rf} 0,6)$ menunjukkan senyawa sineol. ${ }^{10}$

Parameter yang digunakan dalam pengukuran uji aktivitas adalah tingkat kekeruhan yang menunjukkan nilai optical density (OD) yang mana menunjukkan tingkat pertumbuhan suatu sel. Pengukuran optical density (OD) menggunakan spektrofotometer yang diukur pada panjang gelombang 595 nm. ${ }^{13}$ Dalam bidang mikrobiologi optical density (OD) digunakan sebagai satuan hitungan, karena optical density (OD) sebanding dengan kepekatan sel didalam suspensi biakan. ${ }^{14,15} \quad \mathrm{IC}_{50}$ dihitung sebagai aktivitas antiproliferasi untuk melihat konsentrasi sampel yang dibutuhkan dalam menginhibisi 50\% sel leukimia P388.

Parameter sitotoksik yang digunakan dalam mengukur aktivitas minyak atsiri rimpang temulawak ini menggunakan prinsip kemampuan konversi substrat 3-(4,5- dimetilthiazol-2-il)-2,5- dipheniltetrazolium bromid (MTT) menjadi formazan ungu oleh enzim suksinat dehidrogenase pada sel hidup. Reagen MTT akan memberikan warna pada sel leukemia P388 yang terinhibisi yang dimetabolisme oleh aktivitas enzim suksinat dehidrogenase pada mitokondria sel yang bertahan hidup untuk menghasilkan reaksi farmazan yang berwarna ungu. ${ }^{13}$

Hasil uji aktivitas minyak atsiri temulawak terhadap sel leukemia P388 menunjukkan bahwa 50\% sel leukemia P388 dapat dihambat oleh minyak atsiri rimpang temulawak pada konsentrasi $15,5 \mu \mathrm{g} / \mathrm{mL}$. Hasil penelitian ini menunjukkan bahwa minyak atsiri temulawak bersifat sebagai antiproliferasi pada sel leukimia P388 yang dapat disebabkan oleh aktivitas senyawasenyawa yang terkandung di dalamnya diantaranya yaitu senyawa terpenoid sebagaimana hasil pada identifikasi dengan KLT. Hal ini juga telah dijelaskan dalam beberapa penelitian sebelumnya, diantaranya yaitu bahwa senyawa ar-tumeron dalam minyak atsiri bersifat antiproliferatif melalui mekanisme apoptosis yang diinduksi oleh aktivitas antioksidan dan antiplatet pada sel leukemia manusia dan murine 313316, senyawa golongan terpenoid dalam minyak atsiri temulawak diketahui mampu menghambat aktivasi karsinogen kimia,

Tabel 3. Perhitungan ANOVA uji aktivitas minyak atsiri rimpang temulawak pada sel leukimia P388

\begin{tabular}{lccccc}
\hline \multicolumn{1}{c}{ Sumber } & db & JK & KT & $\mathbf{F}_{\text {hitung }}$ & $\begin{array}{c}\mathbf{F}_{\text {tabel }} \boldsymbol{\alpha}=\mathbf{0 , 0 1} \\
(\mathbf{6 , 1 4 )}\end{array}$ \\
\hline Konsentrasi & 6 & 0,0186 & 0,003 & 3 & 4,46 \\
Galat & 14 & 0,0141 & 0,001 & & \\
Total & 20 & 0,0327 & & & \\
\hline
\end{tabular}


dan menginaktivasi pengaktifan genotoksik serta menghambat jalur transduksi yang penting untuk perkembangan tumor, ${ }^{16}$ juga adanya senyawa xanthorrizol dalam rimpang temulawak diketahui dapat menghambat sel kanker payudara Ymb-1, T47D dan MCF-7. ${ }^{10-}$ ${ }^{12}$ Namun, berdasarkan uji statistik hasil uji aktivitas ini menunjukkan tidak ada pengaruh nyata peningkatan konsentrasi minyak atsiri rimpang temulawak terhadap kenaikan aktivitasnya . Hal ini perlu dilakukan uji lebih lanjut pada variasi konsentrasi yang berbeda agar dapat mengetahui efektivitas dan tingkat keamanan penggunaan minyak atsiri rimpang temulawak dalam penghambatan sel leukemia P388.I

\section{Simpulan}

Minyak atsiri rimpang temulawak mempunyai aktivitas antiproliferasi terhadap sel leukemia P388 yang diuji menggunakan metode MTT dengan nilai $\mathrm{IC}_{50}=15,5 \mu \mathrm{g} /$ $\mathrm{mL}$. Aktivitas ini dapat disebabkan oleh adanya kandungan senyawa golongan terpenoid yang ditunjukkan dalam hasil identifikasi menggunakan KLT. Oleh karena itu dapat dilakukan penelitian lebih lanjut untuk mengetahui senyawa aktif tunggal pada minyak atsiri rimpang temulawak yang memiliki peran penting dalam aktivitasnya menghambat proliferasi sel leukimia P388.

\section{Daftar Pustaka}

1. Rofinda, Z.D. Tinjauan Pustaka Kelainan Hemostasis pada Leukemia. Jurnal Kesehatan Andalas. 2012;1(2):68-74.

2. Hao T., Talley Min Li., Buck, A., Chen, WY. An Emerging Trend of Rapid Increase of Leukemia but not All Cancers in The Aging Population in the United States/ Scientific Reports. 2019; 9(1207):1-13.

3. Elrayess, R.A., Nageh, H. Anticancer Natural Products: A Review. Cancer Studies and Molecular Medicine. 2019;5(1):14-25.

4. David B, Wolfender J.L, Dias DA.The Pharmaceutical Industry and Natural Products: Historical Status and New Trends. Phytochemistry Reviews. 2015;14:299-315.
5. Saleh, N.A.M., Ismail, S., and Halim, M.R.Ab. Effects of Curcuma xanthorrhiza Extracts and Their Constituents on Phase II Drug-metabolizing Enzymes Activity. Pharmacognosy Research. 2016;8(4):309-315.

6. Akhila N., Augustine A., Sreeraj Gopi. Non-Curcuminoids from Turmeric and Their Potential in Cancer Therapy and Anticancer Drug Delivery Formulations. Biomolecule. 2019;9(1):1-67.

7. Jacob, James N., Toloue, Masoud. Biological Studies of Turmeric Oil, Part 1: Selective in vitro Anticancer Activity of Turmeric Oil (TO) and TOPaclitaxel Combination. Natural Product Communication. 2013;8(6):807-810.

8. Ibrahim,J., Fadlina,C.S., Muhammad,N.Q., Correlation between Chemical Composition of Curcuma domestica and Curcuma xanthorrhiza and Their Antioxidant Effect on Human LowDensity Lipoprotein Oxidation. EvidenceBased Complementary and Alternative Medicine. 2012:1-12.

9. Oon, S.F., Nallappan, M., Tee, T.T., Shohaimi, S., Kassim, N.K., Sa'ariwijaya, M.S.F., Cheah, Y.H. Xanthorrhizol: a Review of Its Pharmacological Activities and Anticancer Properties. Cancer Cell International. 2015;15(100):1-15

10. Udin, Z., Cytotoxic Activity Of Xanthorrhizol From Curcuma Xanthorrhiza Roxb.'S Volatile Oil Toward Ymb-I Breast Cancer Cell. Indonesian Journal of Applied Chemistry. 2013;15(1): 23-29.

11. Musfiroh, I., Udin. L.Z., Diantini, A., Levita, J, Mustarichie, R., dan Muchtaridi. Aktivitas Antiproliferasi Ekstrak, Fraksi Etil Asetat Dan Isolat Rimpang Temulawak (Curcuma Xanthorrhiza Roxb.) Terhadap Sel Kanker Payudara T47D. Bionatura. 2011;13(2):93-100.

12. Musfiroh, I., Muchtaridi, M., Muhtadi, A., Diantini, A., Hasanah, A.N., Udin, Z., Susilawati, Y., Mustarichie, R., Kartasasmita, R.E., Ibrahim, S. Cytotoxicity Studies of Xanthorrhizol 
and Its Mechanism Using Molecular Docking Simulation and Pharmacophore Modelling. Journal of Applied Pharmaceutical Science. 2013;3(06): 007-015.

13. Xu, X., Gao, X., Jin, L., Bhadury, P.S., Yuan, K., Hu, D., Song, B., Yang, S. Antiproliferation and Cell Apoptosis Inducing Bioactivities of Constituents from Dysosma versipellis in PC3 and Bcap-37 Cell Lines. Cell Divison. 2011; 6(14): 1-12.

14. Koutsoni, Olga S., Kalliopi Karampetsou, and Eleni Dotsika. In vitro Screening of Antileishmanial Activity of Natural Product Compounds: Determination of IC50, CC50 and SI Values. Bio Protocol. 2019; 9(21):1-3

15. Smee, Donald F., Brett L. Hurst, W. Joseph Evans, Nathan Clyde, Sean
Wright, Christopher Peterson, Kie-Hoon Jung, and Craig W. Day. Evaluation of Cell Viability Dyes in Antiviral Assays with RNA Viruses that Exhibit Different Cytopathogenic Properties. Journal of Virological Methods.2017;246: 51-57.

16. Aqeela, A., Ghalib, O., Khan, M.A., Jose, J., Afzal, M. Chemistry and Biochemistry of Terpenoids from Curcuma and Related Species. Journal of Biologically Active Products from Nature. 2013;3(1):1-20.

17. Barton, B., Peat, Jennifer., Medical Statixtics : A Guide to SPSS, Data Analysis and Critical Appraisal, Second Edition, John Wiley \& Sons. Ltd., USA. $2014: 113$.

18. Rahman Ab., Jamalludin. Biref Guidelines for Methods and Statistics in Medical Research, Springer, Singapore. 2015: 78. 